\title{
The Ultrastructure of $\mathbf{S}$ and $\mathrm{R}$ Variants of Brucella abortus Grown on a Lifeless Medium
}

\author{
By S. DE PETRIS, GIOANNA KARLSBAD and R. W. I. KESSEL \\ Laboratory of Electron Microscopy, Clinica del Lavoro 'L. Devoto', \\ University of Milan, Italy
}

(Received 28 October 1963)

\begin{abstract}
SUMMARY
An electron microscopic investigation was carried out on thin sections of both $\mathbf{S}$ and $\mathbf{R}$ variants of Brucella abortus, strain SA: no ultrastructural differences were noted between the two variants.

The cells are limited by a cell wall, comprising an outer triple-layered membrane (65-80 $\AA$. thick) and an inner homogeneous layer of variable thickness, and a triple-layered cytoplasmic membrane about $70 \AA$. thick. The cytoplasm and nucleoplasm of brucellae are similar to those of other bacteria. A characteristic feature of these organisms is the presence of membranous structures (300-800 $\AA$. in diameter) associated with the cytoplasmic membrane. These 'peripheral formations', which occur singly or in clusters, do not appear to arise by obvious invagination of the cytoplasmic membrane.

No evidence has been obtained for the existence of capsules in virulent brucellae.
\end{abstract}

\section{INTRODUC'TION}

The aim of the present investigation was to study the ultrastructure of Brucella abortus grown either on a lifeless medium or within monocytes maintained in vitro. To our knowledge no detailed study of this organism, employing present-day techniques of electron microscopy, has been published to date.

The first paper in this series deals with the morphology of $\mathbf{S}$ and $\mathbf{R}$ variants of Brucella abortus strain sA, grown on a lifeless medium. Our interest in comparing both variants stemmed from the notion that the mutational event occurring in B. abortus, which results in a change of genotype from $\mathbf{S}$ to non $\mathbf{S}$ (e.g. $\mathbf{R}$ or $\mathbf{M}$ ), is associated with a variety of phenotypic changes. These include loss of or decrease in virulence, loss of the ability to multiply intracellularly (Braun, Pomales-Lébron \& Stinebring, 1958), change in colonial morphology from smooth to non-smooth (e.g. rough or mucoid), change in surface properties resulting in agglutination, change from sensitivity to resistance to brucella phage (Stinebring \& Braun, 1959), and changes in antigenic composition. These alterations, and particularly the last four, suggested that morphological changes may occur in the surface structure of the bacteria. It seemed interesting therefore to investigate whether the above phenotypic changes would be reflected in ultrastructural differences detectable with the electron microscope. 


\section{METHODS}

Brucella abortus, strain sA (Braun et al. 1958) was used. S and $\mathbf{R}$ variants, labelled respectively SA-S and SA-R, were grown from single colony isolates. Cultivation was upon a modified tryptose agar compounded from: Bacto tryptose agar, 41 g.; dextrose, 10 g.; aqueous thiamine hydrochloride $(0.01 \%$, w/v), 1 ml.; aqueous $\mathrm{FeSO}_{4} \cdot 7 \mathrm{H}_{2} \mathrm{O}(0 \cdot 183 \%$, w/v), $1 \mathrm{ml}$.; distilled water to $1 \mathrm{l}$., sterilized by autoclaving for $20 \mathrm{~min}$. at $120^{\circ}$.

After 48-96 hr growth on tryptose agar, individual colonies were punched out and immersed in fixative. Often colonies were overlayed with agar to prevent their subsequent dissolution during fixation; this occurred readily with smooth colonies. In some cases slant-grown organisms were suspended directly in the fixative, centrifuged, and the resulting pellets treated as the individual colonies. The organisms were fixed either in $1 \%(\mathrm{w} / \mathrm{v}) \mathrm{OsO}_{4}$ by the method of Kellenberger, Ryter \& Séchaud (1958), or for 1-2 hr at room temperature in $2 \%(\mathrm{w} / \mathrm{v})$ potassium permanganate buffered either according to Luft (1956) or in distilled water. This step was followed by post-fixation for $1 \mathrm{hr}$ in $1 \%(\mathrm{w} / \mathrm{v})$ uranyl acetate in distilled water. Fixation in potassium permanganate was carried out to permit subsequent comparison with monocyte-grown brucellas (Karlsbad, Kessel, de Petris \& Monaco, 1964). The bacteria were dehydrated in a graded series of ethanol in water mixtures, $\mathbf{2 5} \%(\mathrm{v} / \mathrm{v})$ and $\mathbf{5 0} \%(\mathrm{v} / \mathrm{v})$ for $10 \mathrm{~min}$. each, $\mathbf{7 5} \%(\mathrm{v} / \mathrm{v})$ for $20 \mathrm{~min}$., and absolute ethanol for $1 \mathrm{hr}$. They were then embedded in Araldite according to the method of Glauert \& Glauert (1958) modified as follows: infiltration in a 50:50 absolute ethanol + Araldite mixture for $1 \mathrm{hr}$ and then in three changes of Araldite mixture each for $1 \mathrm{hr}$ at $60^{\circ}$. Polymerization was carried out at $80^{\circ}$ for $48 \mathrm{hr}$.

Sections were cut with a Servall Porter-Blum microtome using glass knives. Most sections of cells fixed with $\mathrm{OsO}_{4}$ were stained with $5 \%(\mathrm{w} / \mathrm{v})$ uranyl acetate in $50 \%(\mathrm{v} / \mathrm{v})$ ethanol. The sections were examined with a Siemens Elmiskop I electron microscope working at magnifications of 20,000 and 40,000 .

\section{RESULTS}

No gross differences were observed between the virulent $(\mathbf{S})$ and the avirulent $(\mathbf{R})$ strains of Brucella abortus; the following description will therefore apply to both strains unless otherwise stated.

General appearance (Pl. 1, fig. 1). Brucellas examined in thin sections appeared as rounded or oval structures having a cross-sectional diameter of about $0.5 \mu$ and a maximum length of between 1.0 and $1.2 \mu$. Occasional longer forms (of up to $1 \cdot 5-1 \cdot 7 \mu$ ) were seen; these cells, which made up only a small fraction of the population, may represent cells at some stage of cell division.

Cells were invariably limited by a multilayered envelope. Proceeding inward from the surface, this consisted of an outer triple-layered coat, a middle homogeneous layer of variable thickness and an inner triple-layered membrane. We shall refer to the outer two components as 'cell wall' and to the inner one as 'cytoplasmic membrane'.

Cell wall. The outline of the cells fixed with permanganate was generally smooth (Pl. 2, fig. 4); in the cells treated with Luft's fixative (Pl. 2, figs. 2, 3) it was slightly 
wavy and less distinct than in the cells fixed with $\mathrm{KMnO}_{4}$ in distilled water. The outer (65-70 A. thick) component of the cell wall consisted of two symmetrical, electron dense layers, each 15-20 A. thick, enclosing a $30 \AA$ A. electron transparent space (Pl. 2, fig. 4). In the osmium fixed cells (Pl. 1, fig. 1; Pl. 2, figs. 5, 7; Pl. 3, figs. 15, 18) the outer component was usually wavy and appeared somewhat thicker (about 20-40-20 A.) than in the permanganate fixed preparations. The inner component of the cell wall consisted of a relatively homogeneous layer lacking a clearly defined structure (e.g. Pl. 1, fig. 1; Pl. 2, figs. 2, 3). Its texture was always finer and more homogeneous than that of the cytoplasm. In the permanganatefixed preparations, its density was in some cases comparable to that of the cytoplasm; in the osmium-fixed cells it was always markedly lower in density, and never contained| the ribosome-like particles which were clearly visible in the cytoplasm. This inner component usually varied in thickness between 100 and $200 \AA$., but in some cases it was much thicker, on occasion occupying a considerable portion of the volume of the bacterium (Pl. 2, figs. 2, 3). Although some of the images might have resulted either from oblique sectioning of the cells or from technical artifacts, close inspection of the micrographs showed that this could not always be the case.

No structures outside the cell wall were visible in either $R$ or $S$ strains. In particular no capsular material could be detected in the $S$ strains. In the colonies of the $R$ variant, areas of contact between cells were often observed (Pl. 1, fig. 1; Pl. 4, fig. 22). In these regions the outlines of the apposed surfaces were straight and the outer layers of the two cell walls appeared in direct contact, without any intervening material between them. Some cells (Pl. 1, fig. 1) showed areas of contact with more than one other cell; these areas were apparently distributed at random on the cell surfaces. We have been unable so far to demonstrate such extensive areas of contact in $\mathbf{S}$ colonies.

Cytoplasmic membrane (Pl. 2, figs. 4, 5, 6). In both permanganate and osmiumfixed preparations the cytoplasmic membrane appeared smooth and regular and consisted of two electron dense layers, each 15-20 A. thick, enclosing a $30 \AA$. electron transparent space. The two dense layers were neither as clearly defined nor as deeply stained as the corresponding dense layers of the outer component of the cell wall. Moreover, in the osmium-fixed cells, the plasma membrane was often invisible, being replaced by a lighter space of comparable dimensions, which was sometimes limited by only faint traces of the electron dense layers (Pl. 1, fig. 1). The plasma membrane was always in direct contact with the cytoplasm of the cell, even in cells from which the outer cell wall component had become detached due to artifacts (Pl. 3, fig. 15).

Peripheral formations. These membranous structures referred to hereafter as peripheral formations were observed in many cells in contact with, or close to, the cytoplasmic membrane, and appeared as closed or open structures. When closed they were circular or elongated (Pl. 1, fig. 1; Pl. 3, figs. 14, 16) and were separated from the plasma membrane (in sections where this was visible) by a distance never exceeding $0 \cdot 1 \mu$. The open structures (Pl. 3, figs. 8, 15, 17, 18) were semi-circular or horseshoe-shaped formations whose open ends usually terminated at the level of the plasma membrane. Often the relation of these structures to the plasma membrane was not clearly defined, usually because this, unlike the formations themselves, was not sharply outlined. In a few cases the peripheral formations seemed 
to arise by invagination of the plasma membrane (e.g. Pl. 3, fig. 9). In most cases, however, the plasma membrane appeared continuous across the open ends of the formations (Pl. 3, figs. 8-13, 15, 18) which seemed directly applied to the inner layer of the membrane. The overall dimensions of these peripheral formations varied from 300 to $800 \AA$. They were limited by a triple-layered membrane about $90 \AA$. thick made up of two $30 \AA$. electron dense layers enclosing an electron transparent region of the same thickness. In some micrographs the dense layers had a granular appearance ( $\mathrm{Pl} .3$, figs. 10, 12). The material enclosed by this membrane appeared fairly homogeneous and of variable electron density often clearly greater than that of the extracytoplasmic material (Pl. 3, figs. 8, 10). Although the dimensions of the membrane limiting the peripheral formations were of the same order as those of the cytoplasmic membrane, the electron density of the outer two layers was often far greater in the case of the peripheral formations (e.g. Pl. 3, figs. 10, 13, 18).

While most cells showed only one or a few peripheral formations, some cells contained rows of them closely arranged for considerable lengths along the bacteria (Pl. 3, figs. 13, 14, 17). In some cases, in cells sectioned tangentially ( $\mathrm{Pl}$. 3, fig. 16), up to ten of these bodies were found grouped together. On occasion peripheral formations appeared to be associated with the region of constriction formed in the process of cell division (Pl. 4, fig. 19 and probably also Pl. 3, fig. 16).

The frequency of occurrence of the peripheral formations seemed to vary considerably from culture to culture.

Cytoplasm and nucleoplasm. The general appearance of the structures contained within the cytoplasmic membrane was similar to that described for other bacteria (Pl. 1, fig. 1). Two components were observed: a granular electron dense component (cytoplasm), and a less dense component (nucleoplasm) consisting of filaments embedded in a homogeneous electron transparent material. There seemed to be no definite pattern in the distribution of these two components. They were either intimately mixed, or the denser component had a peripheral distribution with one or a few small clumps appearing in the central, clearer region.

In osmium-fixed cells the cytoplasm comprised a coarser, denser, material consisting of granules 100-150 A. in diameter, not sharply outlined and presumably corresponding to ribosomes, and a finer component either intermixed with the former or forming clumps within the nucleoplasm (Pl. 1, fig. 1). At higher magnifications and after staining with uranyl acetate, many of the denser granules showed evidence of substructure (Pl. 4, fig. 20). They often appeared to consist of two dense subunits 80-90 $\AA$. long, separated by a lighter space. The random orientation of these pairs of subunits in the field indicated that they were not the result of astigmatism. They might correspond to the subunits of bacterial ribosomes (see electron microscopic observations of Huxley \& Zubay, 1960) or to parts of the ribosomes specifically revealed by our method of fixation and staining. In permanganate-fixed cells the cytoplasm appeared more uniformly granular and coarser, particularly in the preparations fixed with permanganate in distilled water (Pl. 2, figs. 2, 3, 4).

The filaments of the nucleoplasm had the appearance seen in other bacteria. They were usually arranged at random, while at times they appeared to form 'whorls' (Pl. 2, figs. 2, 3). They measured about $20 \AA$. in diameter as estimated in photographs with the best resolution obtainable. Their appearance was as well defined in cells fixed with osmium as in those fixed with Luft's permanganate 
solution, thus confirming that the latter, followed by treatment with uranyl acetate, is a suitable fixative for bacterial DNA.

Except for peripheral formations, no other structures were normally present in the ground cytoplasm of brucellas. In a few cells of one culture, however, some membranous elements were noted (Pl. 4, fig. 21). These were larger than the peripheral formations and did not seem to be related to the plasma membrane. Such structures recall those described by Caro (1961) in Escherichia coli. The cells of some cultures, moreover, contained at times a rounded extremely dense body (about 500-800 A. in diameter) which was often localized close to a cluster of peripheral formations and appeared very similar to the polyphosphate granules described in other bacteria.

Cell division. Several dividing cells were seen (Pl. 4, fig. 19). Cell division appeared to occur by a process of progressive constriction of the central region of an elongated cell involving both cell wall and cytoplasmic membrane, without any evidence of septum formation. There was no characteristic redistribution of the cell contents during this process. Continuity of cytoplasmic and nucleoplasmic material was still observed in cells showing a marked region of constriction (Pl. 4, fig. 19). The process of cell division in brucellas is thus similar to that described by Conti \& Gettner (1961) in Escherichia coli and is in agreement with the general mechanism of cell division common to all Gram-negative bacteria (Glauert, 1962).

\section{DISCUSSION}

The ultrastructural characters of Brucella abortus are similar to those of the other Gram-negative bacteria so far described. In particular its surface layers, comprising cell wall and cytoplasmic membrane, show features which are becoming recognized as common to all Gram-negative bacteria (Kellenberger \& Ryter, 1958; Ryter, Kellenberger, Birch-Anderson \& Maaløe, 1958; Glauert, 1962; Wyss, Neumann \& Socolofsky, 1961).

The general appearance and dimensions of the outer triple-layered component of the cell wall and of the cytoplasmic membrane are closely similar, especially in preparations fixed with permanganate and subsequently treated with uranyl acetate. According to some authors (Brown, Drummond \& North, 1962; Clarke \& Lilly, 1962) both membranes correspond essentially to the 'unit membrane' described by Robertson (1959) in cells of higher organisms. Such membranes would consist of a bimolecular leaflet of phospholipids bounded on one side by protein and on the other by polysaccharide. (As seen in some micrographs of the accompanying paper (Karlsbad et al. 1964) which show brucellas inside monocytes, fixed with potassium permanganate, the outer component of the bacterial wall appears, in fact, very similar to the membrane of the monocyte's vacuole containing the brucellas.)

Our results with Brucella abortus although compatible with a common structural organization of the outer cell wall component and of the cytoplasmic membrane suggest that the two are not identical; thus the outer cell wall component in osmiumfixed cells appears much more wavy and somewhat thicker than the plasma membrane (in spite of a certain variability in its absolute dimensions in different cells); moreover, the cell wall is always better preserved than the plasma membrane. In fact, while the outer cell wall component is clearly visible in practically all the cells, 
some brucellas in the same sections show well-defined plasma membranes, others only faintly discernible ones and still others no apparent plasma membranes at all. It is interesting to note in this connexion that Robertson (1959) reported a certain variability in the degree of preservation of the triple-layered nature of cell membranes in higher organisms.

Is the intermediate, less dense layer of the envelope of Brucella abortus, a real entity or an artifact? Although the true dimensions of this layer may be greatly modified by the preparative procedure, we believe that a space between the outer component of the cell wall and the plasma membrane is also present in vivo, because this region is usually occupied by homogeneous electron dense material (PI. 2, figs. 2,3 ) which retains its dense and homogeneous texture even in cells which show considerable 'retraction' of the cytoplasm from the surface of the cell (usually at one pole of the cell). Much cytoplasmic 'retraction' in a marine pseudomonad undergoing transformation into spheroplasts was observed by Brown et al. (1962) who considered the extracytoplasmic material indistinguishable from the cytoplasm. Our results indicate that the extra-cytoplasmic material, being more homogeneous and less electron dense, is clearly distinguishable morphologically from the cytoplasm. It is, moreover, always devoid of 'ribosome-like' particles. This intermediate layer might comprise the rigid, mucopeptide component of the cell wall which was demonstrated by Weidel, Frank \& Martin (1960) and which is accepted by several authors as constituting the inner portion of the cell wall of Gram-negative bacteria (e.g. Salton, 1962; Clarke \& Lilly, 1962).

Membranous structures of varying degrees of complexity have been observed in almost all bacteria examined in thin sections. The peripheral formations found in brucellas, consisting of a simple vacuole limited by a single triple-layered membrane, appear simpler than those described in the majority of bacteria, and are characteristically aggregated in clusters in some regions of the cytoplasmic membrane. Structures of a simple type, fairly similar to those associated with the plasma membrane in Brucella abortus, have been described in Azotobacter vinelandii (Wyss et al. 1961), Staphylococcus aureus (Suganuma, 1961) and Spirillum serpens (Chapman \& Kroll, 1957). In some cases evidence was presented that these structures arise by true invagination of the plasma membrane (e.g. Fitz-James, 1960; Wyss et al. 1961; Suganuma, 1961). In the case of brucellas it was not possible to reach a definite conclusion on this point. All the electron microscopic images of peripheral formations are compatible with the assumption that they always lie in contact with the plasma membrane. The closed formations can also be interpreted as in contact with the plasma membrane, but sectioned in a parallel plane (as shown schematically in Fig. $1 e-e^{\prime}$ and $\left.f-f^{\prime}\right)$. Their dimensions are of the same order as the thickness of the thin sections; thus they often occupy only part of the thickness of the section, and so, as shown schematically in Fig. 1, different electron microscopic images may be obtained depending on the orientation and position of the peripheral formations with respect to the plane of the thin section. Images which could be interpreted as true invaginations of the plasma membrane (corresponding to Fig. $1 b-b^{\prime}$ and possibly $a-a^{\prime}$ ) were observed only in a few cases (Pl. 3, fig. 9). On the contrary in most micrographs the plasma membrane appeared clearly continuous across the open ends of the peripheral formations; in these cases the layers limiting the open formations did not cross the plasma membrane and, 
in particular, the inner one did not show continuity with the outer layer of the plasma membrane. Images like the latter are hardly compatible with the existence of true invaginations (Fig. $1 c-c^{\prime}, d-d^{\prime}$ ). Thus the question remains unanswered. It cannot be excluded that the two contradictory appearances are due to some artifact. In any case the membrane limiting these bodies, although similar in dimensions to the adjacent plasma membrane, can be clearly distinguished from it both because it is usually more heavily stained (and sometimes granular), well preserved, and clearly outlined even in cells where the plasma membrane is hardly
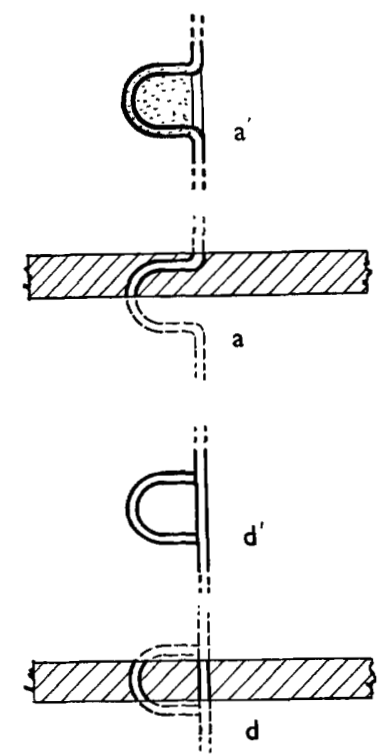
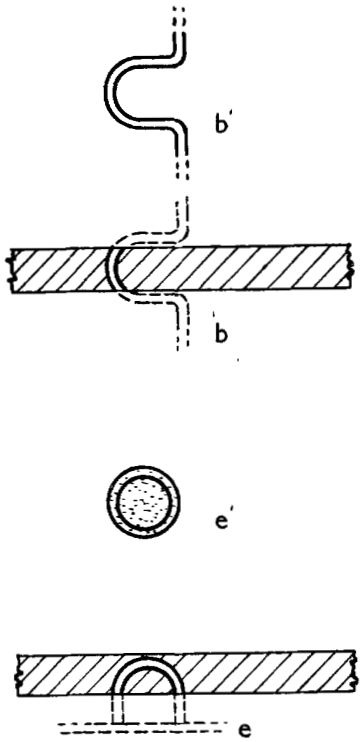
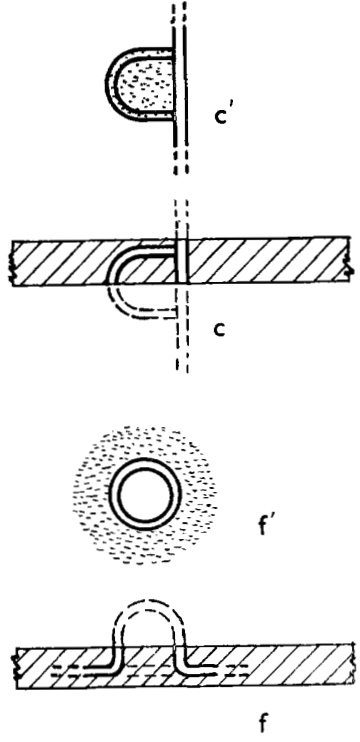

Fig. 1. Diagrams $a, b, c, d$ and $e$ represent schematically some possible orientations of peripheral formations with respect to the thickness of the sections. Diagrams $a^{\prime}, b^{\prime}, c^{\prime}, d^{\prime}$ and $e^{\prime}$ represent the corresponding images as observed in electron micrographs. Such images may result from the superimposition of structures in different planes of the section. In $a^{\prime}, c^{\prime}$ and $e^{\prime}$ the contents of the peripheral formations may appear more electron dense than in the other cases, due to the presence of a markedly electron dense membrane roughly parallel to the plane of the section.

or not at all visible. The above facts suggest that the formations, although possibly derived from the plasma membrane, are structurally and perhaps functionally distinct from it.

As regards the significance of the peripheral formations, we consider it unlikely that they may correspond to pinocytic vesicles (as suggested by Suganuma (1961) for the small 'caveolae' in Staphylococcus aureus), both because we found no evidence of their detachment from the plasma membrane and because they differ in appearance from the pinocytic vacuoles of higher cells. They could correspond to sites for the synthesis of cell wall material (as suggested by Glauert, Brieger \& Allen (1961) for the 'membranous pockets' found in Bacillus subtilis), an interpretation which could explain the presence of peripheral formations in the region of constriction occurring during cell division. Alternatively they could be interpreted as primitive mitochondria, a view favoured by several authors in considering membranous structures observed in other bacteria (Wyss et al. 1961; Fitz-James 
1960; Shinohara, Fukushi \& Suzuki, 1957). In either case the simple formations observed in Brucella abortus may correspond to the more complex 'peripheral bodies' seen in other bacteria. Other interpretations cannot, however, beruled out and no conclusions can be drawn merely on the basis of our morphological observations.

As mentioned previously, no morphological differences were observed between $\mathbf{S}$ and $\mathbf{R}$ Brucella abortus in parallel studies. In particular no evidence was collected for the existence of capsules in $\mathbf{S}$ types. Capsules surrounding virulent (i.e. $\mathbf{S}$ ) brucellas have been described by Huddleson (1940), Mickle (1940) and others using optical methods. Their appearance, however, has remained a matter of dispute (see, for example, Huddleson, 1941). The very thick capsules of relatively low electron density, seen to surround brucellas by earlier electron microscopists (e.g. von Borries, Ruska \& Ruska, 1938; Lembke, Kornlein \& Frahm, 1950; Malfatti \& Ithurralde, 1951) may well have been due to experimental artifacts. Their observations were made, in fact, on whole exsiccated bacteria lying on supporting films. Our own study on thin sections of the organisms provides no evidence for the existence of capsules or of any material external to the cell wall.

We found no evidence to support the notion that variation from $\mathbf{S}$ to $\mathbf{R}$ might be associated with morphological changes in surface structures. Similarly, negative results have been reported by Scanga (1958) in his study of Salmonella variants. It seems reasonable to suppose that these surface changes do not induce morphological modifications detectable with the electron microscope.

The only possible difference noted between $\mathbf{S}$ and $\mathbf{R}$ strains consisted in the presence of quite extensive areas of contact between two or more cells in $\mathbf{R}$ colonies, while no such contacts could be demonstrated in $\mathbf{S}$ colonies. In spite of the caution necessary to evaluate a negative result, also on account of the variability in the incidence of the contacts in the $\mathbf{R}$ colonies, we believe that these contacts may represent a differential feature between $S$ and $R$ variants. Their presence or absence probably depends on differences in the surface properties of $\mathbf{S}$ and $\mathbf{R}$ strains and may in turn be responsible for the ready disintegration of $\mathbf{S}$ colonies during fixation, not observed with the $\mathbf{R}$ forms (see Methods), and possibly also for the 'rough' versus 'smooth' appearance of the colonies themselves.

This study was carried out while one of us (R. W. I. Kessel) was a National Science Foundation Postdoctoral Fellow. He would like to thank Professor E. C. Vigliani (Director) and Professor B. Pernis of the Clinica del Lavoro 'L. Devoto' for their hospitality and help.

Grateful acknowledgement is also made to Dr Ann Heuer for helpful criticism of this manuscript.

\section{REFERENCES}

Borries, B. von, Ruska, E. \& Ruska, H. (1938). Bakterien und Virus in übermikroscopischer Aufnahme. Klin. Wschr. 17, 921.

Braun, W., Pomales-lébron, A. \& Stinebring, W. R. (1958). Interaction between mononuclear phagocytes and Brucella abortus strains of different virulence. Proc. Soc. exp. Biol., N.Y. 97, 393.

Brown, A. D., Drummond, D. G. \& North, R. J. (1962). The peripheral structure of Gramnegative bacteria. II. Membranes of bacilli and spheroplasts of a marine pseudomonad. Biochim. biophys. Acta, 58, 514. 
CARo, L. G. (1961). Localization of macromolecules in Escherichia coli. I. DNA and proteins. J. biophys. biochem. Cytol. 9, 539.

Chapman, G. B. \& Kroll, A. J. (1957). Electron microscopy of ultrathin sections of Spirillum serpens. J. Bact. 73, 63.

Clarke, P. H. \& Lilly, M. D. (1962). A general structure for cell walls of Gram-negative bacteria. Nature, Lond. 195, 516.

Conti, S. F. \& Getrner, M. E. (1961). Electron microscopy of cellular division in Escherichia coli. J. Bact. 83, 544.

Fitz-James, P. (1960). Participation of the cytoplasmic membrane in the growth and spore formation of bacilli. J. biophys. biochem. Cytol. 8, 507.

Glauert, A. M. \& Glauert, R. H. (1958). Araldite as an embedding medium for electron microscopy. J. biophys. biochem. Cytol. 4, 191.

Glauert, A. M., Brieger, E. M. \& Allen, J. M. (1961). The fine structure of vegetative cells of B. subtilis. Exp. Cell Res. $22,73$.

Glauert, A. M. (1962). The fine structure of bacteria. Brit. med. Bull. 18, 245.

Huddleson, I. F. (1940). The presence of a capsule on brucella cells. J. amer. vet. med. Assoc. 96, 708.

Huddleson, I. F. (1941). The presence of a capsule on brucella cells. Tech. Bull. Mich. agric. Exp. Sta. 177, 11.

Huxley, H. E. \& Zubay, G. (1960). Electron microscope observations on the structure of microsomal particles from Escherichia coli. J. molec. Biol. $2,10$.

Karlsbad, G., Kessel, R. W. I., De Petris, S. \& Monaco, L. (1964). Electron microscope observations of Brucella abortus grown within monocytes in vitro. J. gen. Microbiol. 35,

Kellenberger, E. \& Ryter, A. (1958). Cell wall and cytoplasmic membrane of Escherichia coli. J. biophys. biochem. Cytol. 4, 323.

Kellenberger, E., Ryter, A. \& Séchaud, J. (1958). Electron microscopic study of DNA-containing plasms. II. Vegetative and mature phage DNA as compared with normal bacterial nucleoids in different physiological states. J. biophys. biochem. Cytol. 4, 671.

Lembike, A., Kornlein, M. \& Frahn, H. (1950). Beitrag zum Brucellose-Problem. Z. Bakt. 155, 16.

Luft, J. H. (1956). Permanganate-a new fixative for electron microscopy. J. biophys. biochem. Cytol. 2, 799.

MalfatTi, M. G. \& IThurralde, D. (1951). Valor taxónómica de las imágenes electrónicas de las bacterias de género Brucella. Sem. méd., B. Aires, 98, 704.

Mickle, W. A. (1940). Capsule formation by members of the brucella group. J. infect. Dis. 66, 271.

Robertson, J. D. (1959). The ultrastructure of cell membranes and their derivatives. Biochem. Soc. Symp. 16, 3.

Ryter, A., Kelifenberger, E., Birsch-Andersen, A. \& MaAløe, O. (1958). Étude au microscope électronique de plasmas contenant de l'acide désoxyribonucléique. I. Les nucléoides des bactéries en croissance active. $Z$. Naturforsch. 13B, 597.

Salton, M. R. J. (1962). Cell wall structure and biosynthesis. J. gen. Microbiol. $29,15$.

ScANGA, F. (1958). The relationship of antigenic structure to anatomy in salmonellae. Abstr. 7th int. Congr. Microbiol., p. 430.

Shinohara, C., Fukushi, K. \& SuzukI, J. (1957). Mitochondria-like structures in ultrathin sections of Mycobacterium avium. J. Bact. 74, 413.

Stinebring, W. R. \& Braun, W. (1959). Brucellaphage. J. Bact. 78, 736.

Suganuma, A. (1961). The plasma membrane of Staphylococcus aureus. J. biophys. biochem. Cytol. 10, 292.

Weidel, W., Frank, H. \& Martin, H. H. (1960). The rigid layer of the cell wall of E. coli strain B. J. gen. Microbiol. 22, 158.

Wyss, O., Neumann, M. G. \& Socolofski, M. D. (1961). Development and germination of the Azotobacter cyst. J. biophys. biochem. Cytol. 10, 555. 


\section{EXPLANATION OF PLATES}

\section{Plate 1}

Fig. 1. Brucella abortus, strain SA-R-general structure. Peripheral formations are evident in most of the cells. Areas of contact are present between several of the cells. Fixation according to Kellenberger et al. $\times 108,000$.

\section{Plate 2}

Fig. 2. Brucella abortus, strain SA-s fixed in potassium permanganate buffered according to Luft. With this fixative the outer cell wall layer is less clearly defined than in cells treated with the other fixatives. Note the wide inner cell wall layer composed of homogeneously dense material. $\times 60,000$.

Fig. 3, B. abortus, strain SA-R fixed as in Fig. 2. $\times 60,000$.

Figs. 4-7 show details of the external layers of $B$. abortus.

Fig. 4. B. abortus, strain $\mathrm{SA}-\mathrm{S}$ fixed in potassium permanganate in distilled water. $\times 120,000$.

Fig. 5. B. abortus, strain SA-R fixed according to Kellenberger et al. $\times 120,000$.

Fig. 6. B. abortus, strain sA-s fixed as in Fig. 5. $\times 120,000$.

Fig. 7. B. abortus, strain sA-s fixed as in Fig. 5. $\times 120,000$.

\section{Plate 3}

Figs. 8-18 show examples of peripheral formations. Fixation according to Kellenberger $e$ t al. In many of the sections the cytoplasmic membrane appears continuous across the open ends of the formations; the latter are generally more heavily stained than the adjacent cytoplasmic membrane.

Fig. 8. B. abortus, strain SA-s. $\times 120,000$.

Fig. 9. B. abortus, strain SA-s. In this micrograph a peripheral formation (arrow) may be interpreted as an invagination of the cytoplasmic membrane. $\times 120,000$.

Fig. 10. B. abortus, strain sA-s. The membranes of the peripheral formations in this cell have a granular appearance. The material inclosed in one of them appears markedly denser than the adjacent cell wall. $\times 120,000$.

Fig. 11. B. abortus, strain SA-s. $\times 120,000$.

Fig. 12. B. abortus, strain SA-s. $\times 120,000$.

Fig. 13. B. abortus, strain $\mathrm{SA}-\mathrm{R}$. Several peripheral formations are grouped together in one region of the cell. $\times 120,000$.

Fig. 14. B. abortus, strain sA-R. Row of closed peripheral formations probably cut tangentially

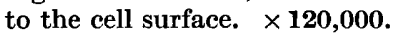

Fig. 15. B. abortus, strain SA-R. $\times 137,000$.

Fig. 16. B. abortus, strain SA-s. Several peripheral formations are grouped together in a region of constriction of a cell which is probably undergoing division. Section cut tangentially to the surface of the bacterium. The dense round body is an artifact. $\times 137,000$.

Fig. 17. B. abortus, strain sA-R. The membranes of the peripheral formations are more heavily stained than the less distinct adjacent cytoplasmic membrane. $\times 120,000$.

Fig. 18. B. abortus, strain SA-R. Group of peripheral formations of which one is particularly heavily outlined; the open ends of this formation are clearly seen to terminate on the inner layer of the cytoplasmic membrane. $\times 200,000$.

\section{Plate 4}

Fig. 19. B. abortus, strain sA-s undergoing division. Note the continuity of the nucleoplasm in the region of cell constriction. Two peripheral formations are also present in this region. $\times 60,000$. Fig. 20. Detail of $B$. abortus, strain SA-R, showing the substructure of the granular particles of the cytoplasm (ribosomes). As a rule these particles appear to be composed of two subunits. Fixation

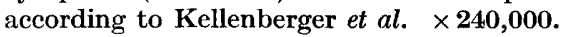

Fig. 21. Circular membranous structure in the cytoplasm of a cell of $B$. abortus, strain SA-s. Compare with the peripheral formations present in the adjacent cell. Fixation according to Kellenberger et al. $\times 60,000$.

Fig. 22. Extensive straight region of contact between two adjacent cells of $B$. abortus, strain SA-R; contact is maintained in spite of gross cytoplasmic retraction in one of the cells. Fixation according to Kellenberger et al. $\times \mathbf{2 2 0 , 0 0 0}$. 

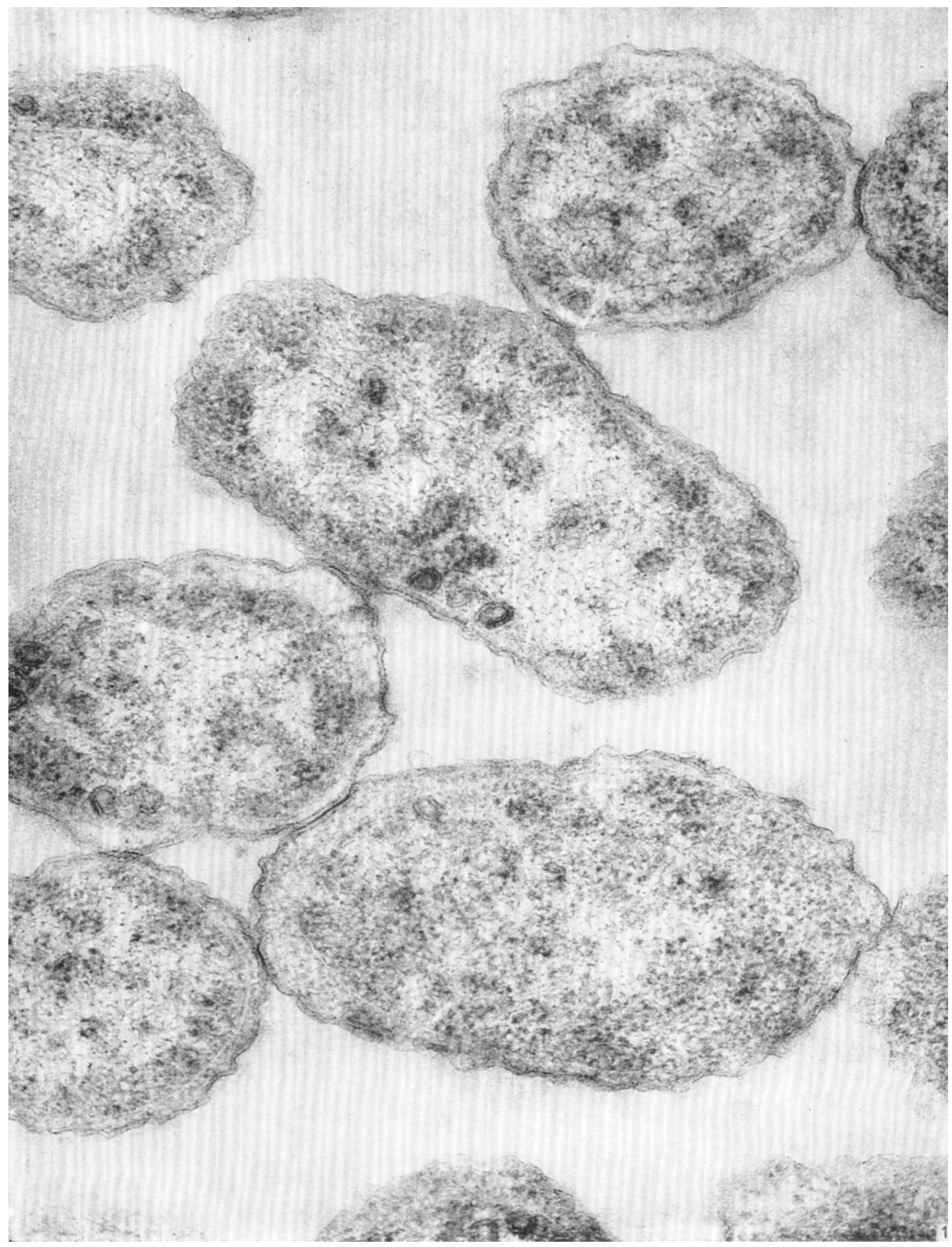
Journal of General Microbiology, Vol. 35, No. 3

Plate 2
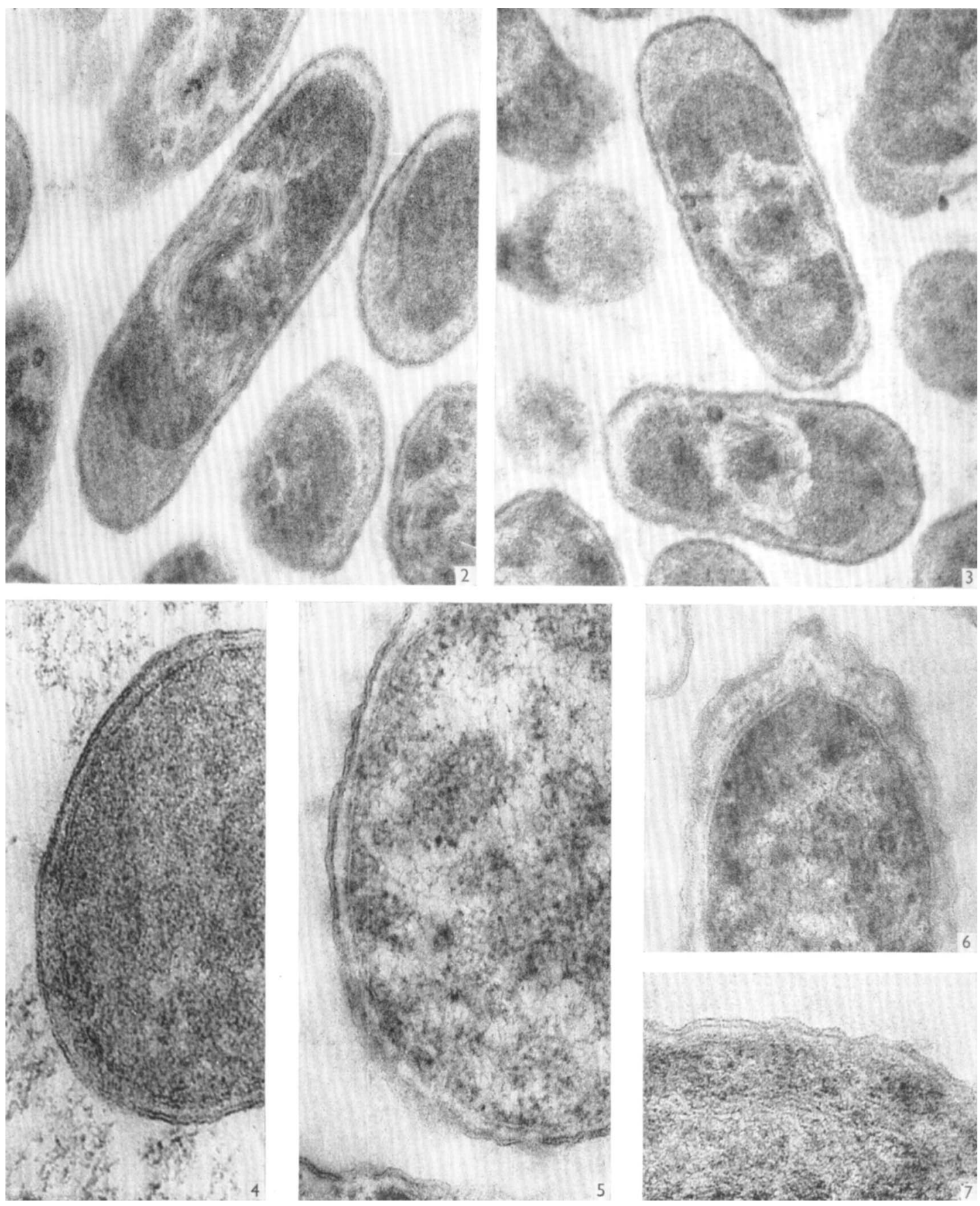

S. DE PETRIS, G. KARISBAD AND R. W. I. KESSEL, 

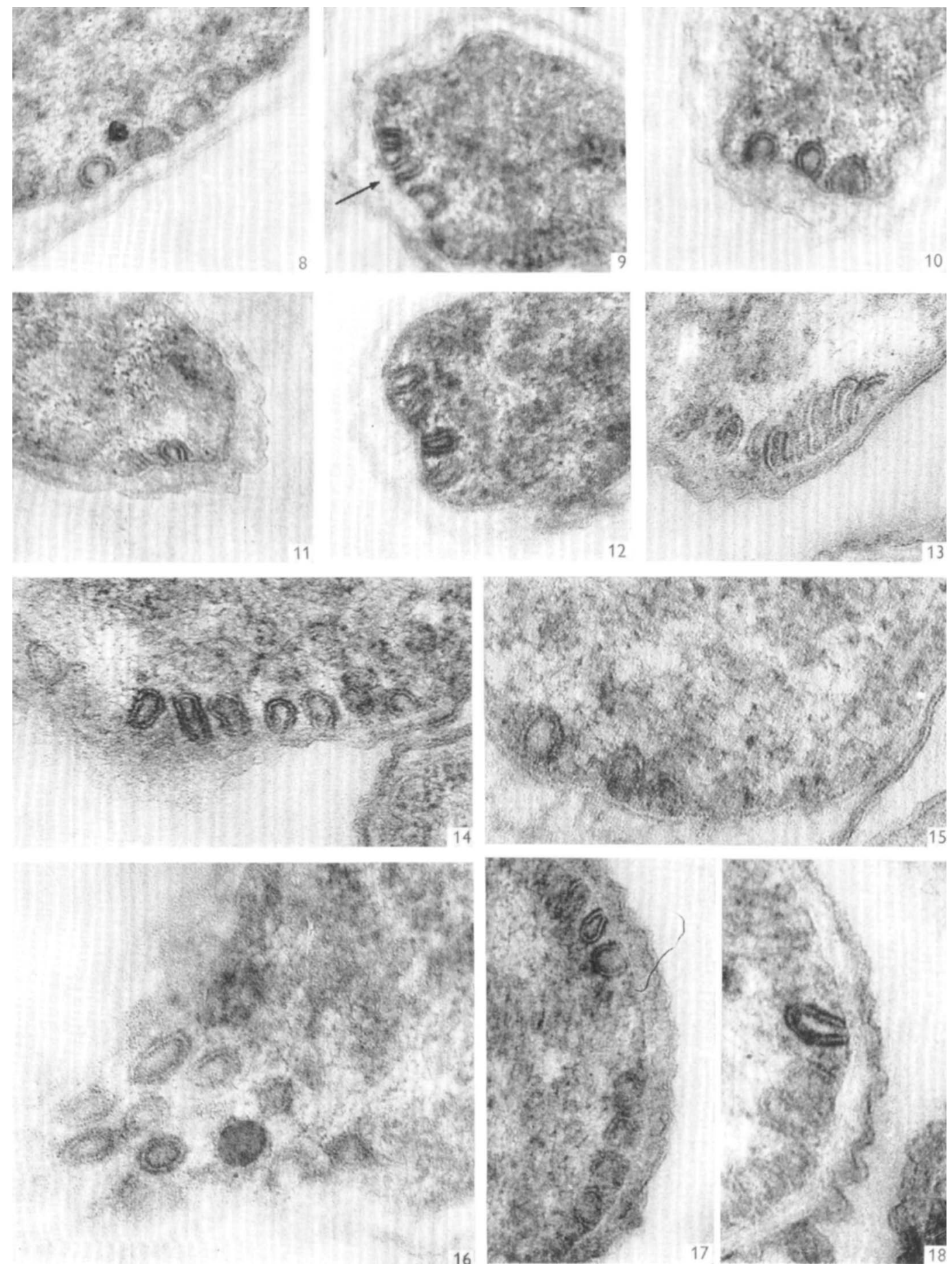

S. DE PETRIS, G. KARLSBAD AND R. W. I. KESSEL 

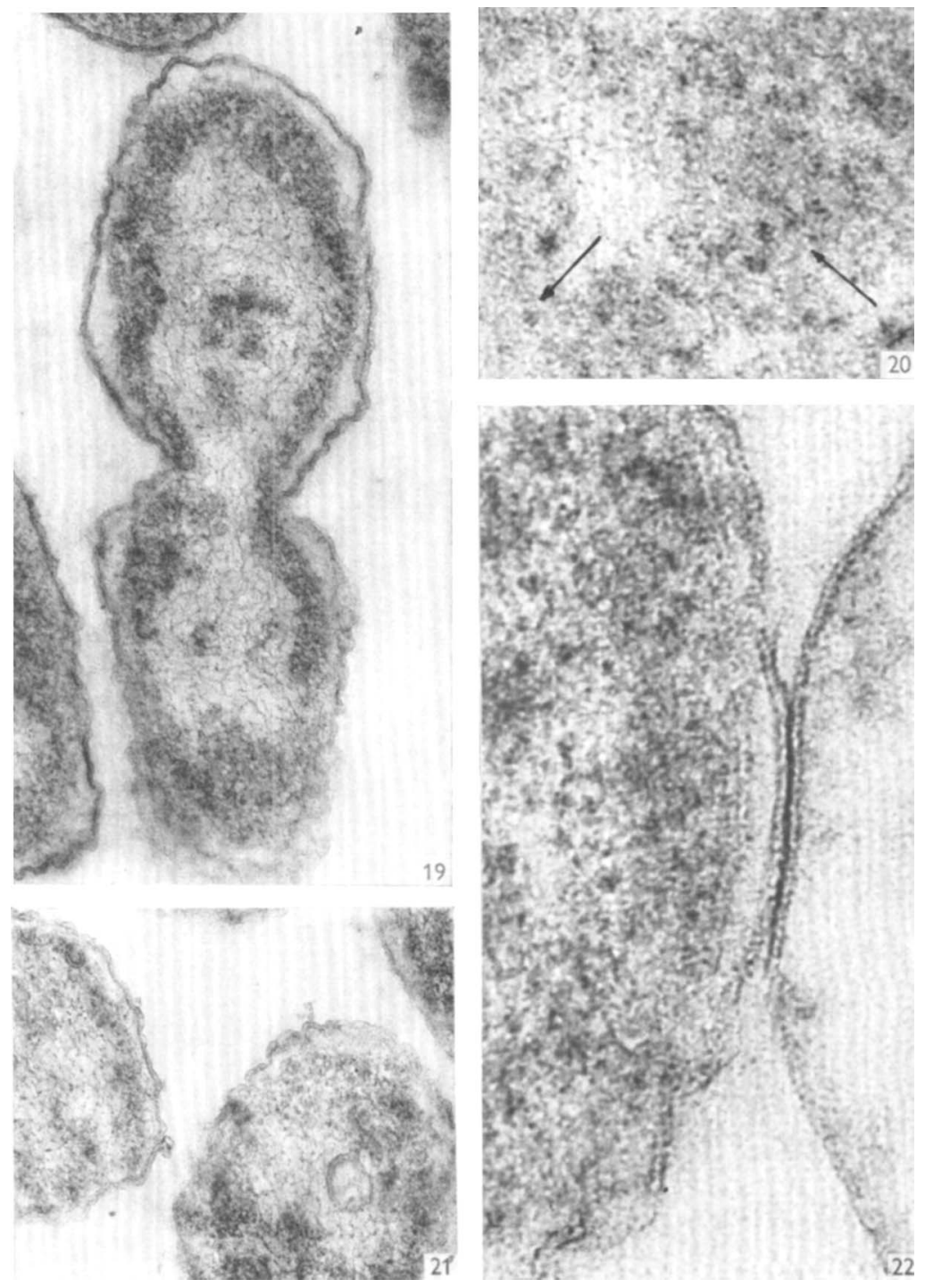

S. ve PETRIS, G. KARLSBAD AND R. W. I. KESSEL 